\title{
Gizi Seimbang pada saat Puasa untuk Meningkatkan Imunitas di Masa Pandemi Covid-19 Pada Ibu di Desa Tonasa Kabupaten Gowa
}

\author{
${ }^{1}$ A. Rizki Amelia AP, ${ }^{2}$ Reza Aril Ahri \\ 1,2Program Studi Kesehatan Masyarakat, Fakultas Kesehatan Masyarakat, Universitas Muslim Indonesia \\ Korespondensi: andirezki.amelia@umi.ac.id
}

\begin{abstract}
Abstrak: Puasa ramadhan sebagai ibadah banyak manfaatnya bagi kesehatan, agar kedua tujuan tersebut dapat tercapai, perlu pengaturan pola makan secara khusus Terutama mengatur asupan gizi saat berbuka dan sahur. Selama berpuasa pola makan akan berubah, karena hanya diperbolehkan makan saat pagi sebelum terbit fajar dan menjelang malam hari. Lambung dibiarkan kosong selama sekitar 13 jam. Umumnya tubuh memerlukan waktu 3-5 hari untuk beradaptasi dengan pola makan yang baru. Dari aspek gizi, puasa paling tidak akan mengurangi asupan gizi, terutama energi sekitar 20-30 persen. Kegiatan pengabdian kepada masyarakat ini dilakukan dengan metode kaji tindak dimana ibu-ibu di Desa Tonasa akan mempraktekkan memasak makanan yang sesuai dengan kebutuhan gizi yang dibutuhkan sesuai umur, kemudian meningkatkan pengetahuan dan pemahaman tentang gizi seimbang selama menjalankan puasa terhadap ibu-ibu PKK di RW 01 selain itu kami sebagai tim pengabdi akan memberikan tips-tips agar keluarga tetap dapat beraktifitas tanpa merasa lemas. Edukasi yang diberikan adalah tentang gizi seimbang pada saat menjalankan puasa melalui Pre dan Post Test. Waktu pelaksanaan pengabdian dilakukan selama 4 bulan. Hasil yang diharapkan pada pengabdian ini adalah dapat meningkatkan pengetahuan dan keterampilan ibuibu mengenai menu gizi seimbang selama menjalankan ibadah puasa
\end{abstract}

Kata Kunci : Gizi Seimbang, Puasa, Covid-19, Imunitas

\begin{abstract}
Fasting Ramadan as worship has many benefits for health, so that these two goals can be achieved, it is necessary to regulate diet specifically, especially regulating nutritional intake during iftar and sahur. During fasting the diet will change, because it is only allowed to eat in the morning before dawn and at night. The stomach is left empty for about 13 hours. Generally, the body takes 3-5 days to adapt to a new diet. From the nutritional aspect, fasting will at least reduce nutritional intake, especially energy by around 20-30 percent. This community service activity is carried out using an action study method where mothers in Tonasa Village will practice cooking food according to the nutritional needs needed according to age, then increase knowledge and understanding of balanced nutrition during fasting for PKK mothers in RW 01 In addition, we as a service team will provide tips so that families can continue to do activities without feeling weak. The education provided is about balanced nutrition when fasting through Pre and Post Tests. The implementation time of the service is carried out for 4 months. The expected result of this service is that it can increase the knowledge and skills of mothers regarding a balanced nutritional menu during fasting.
\end{abstract}

Keywords: Balanced Nutrition, Fasting, Covid-19, Immunity

\section{PENDAHULUAN}

Kasus Covid-19 secara global berdasarkan data pada tanggal 9 september 2021 memberikan gambaran sebanyak 222,406,582 kasus terkonfirmasi Covid-19 dan termasuk 4,592,934 kematian, total vaksin yang telah di berikan sebanyak 5,352,927,296 dilaporkan ke WHO. data kasus di lihat dari situasi menurut WHO dari berbagai negara yang terdampak Virus Covid-19 terdiri dari Amerika 726,560 kasus terkonfirmasi, Eropa 626,496 kasus terkonfirmasi, Asia Tenggara 272,398 kasus terkonfirmasi, Mediterenia Timur 196,810 kasus terkonfirmasi, Afrika 58,370 kasus terkonfirmasi, Pasifik Barat 279,258 kasus terkonfirmasi ${ }^{1}$.

Sebagai perbandingan awal, data pasien Covid-19 menurut jenis kelamin di Indonesia menunjukkan bahwa jumlah pasien laki-laki yang terpapar kasus Covid -19 lebih tinggi dibandingkan

This is an open-access article under the CC BY 4.0 International License

(C) Idea PengabdianMasyarakat (2021)

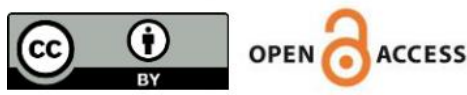


perempuan. Data per 09 September 2021 memberikan gambaran sebanyak 1,0641,4 kasus terkonfirmasi Covid-19, 10,0768 dinyatakan sembuh dan terdapat 2,115 jiwa yang meninggal dunia ${ }^{2}$.

Kasus Covid-19 di indonesia, sejak dua kasus pertama Covid-19 yang diumumkan pada 2 Maret 2020, jumlah kasusnya terus meningkat dan tersebar di 32 provinsi, salah satunya di Sulawesi Selatan, Virus Corona (Covid-19) menyebar begitu cepat di Sulawesi Selatan. Jumlah kasus positif Covid-19 di Sulawesi Selatan yaitu sebanyak 52,767 orang, 46,561 di antaranya sembuh, dan 990 orang lainnya dinyatakan meninggal dunia ${ }^{3}$.

Makassar merupakan kota dengan jumlah kasus yang peningkatannya sangat pesat. data kasus Covid-19 pada tanggal 09 September 2021 tepatnya yang terkonfirmasi sebanyak 47,875 orang, dinyatakan sembuh sebanyak 45,627 orang, 988 orang dirawat dan meninggal dunia sebanyak 1,260 orang (Data per 09 September 2021) ${ }^{3}$.

WHO telah merekomendasikan menu gizi seimbang ditengah pandemi COVID-19. Artinya, disetiap menu makanan harus mencakup nutrisi lengkap, baik itu makronutrien seperti karbohidrat, protein, lemak, serta mikronutrien dari vitamin dan mineral. Namun, untuk membuat fondasi daya tahan tubuh yang kuat (building block),kita harus focus pada asupan protein ${ }^{4}$.

Masyarakat Indonesia umumnya dalam menghadapi bulan puasa melakukan bermacam usaha untuk menghindarkan kekurangan gizi karena frekuensi makan yang berkurang. Hal ini timbul karena rasa khawatir dan banyaknya tawaran iklan yang menjanjikan kekuatan disaat makanna yang masuk berkurang, yaitu dengan mengkonusmsi tambahan berupa vitamin dan mineral. Sehingga tampak bahwa ada kekhawatiran dan ketakutan akan akan kekurangan makan disaat melaksanakan puasa sebulan penuh. Kebiaaan mengkonsumsi sumber karbohidrat sederhana yang lebih banyak dimasa-masa bulan ramadhan sering terjadi. Seperti lebih banyak menyediakan kolak, kue-kue, sirup dan buah, yang semuanya mengandung gula. Disamping sumber karbohidrat dalam lingkungan keluarga yang tingkat ekonominya sudah baik, biasanya penyediaan makanan dan masukan protein hewani untuk anggota keluarga menjadi lebih banyak dibandinkan dengan saat-saat diluar bulan ramadhan.

Menjaga asupan energi dan protein sesuai kebutuhan tubuh sangat penting untuk menjaga berat badan agar status gizi tetap normal sehingga sistem imun tetap terjaga. Selain energi protein, zat gizi makro yang dibutuhkan untuk meningkatkan kekebalan tubuh melawan inflamasi akibat infeksi adalah asam lemak tidak jenuh ganda (poly unsaturated fatty acid/PUFA) ${ }^{5}$. Berbagai vitamin dan mineral berfungsi untuk meningkatkan imunitas tubuh melalui beberapa mekanisme. Beberapa bukti ilmiah dari hasil penelitian banyak bahwa kekurangan zat gizi mikro meningkatkan risiko infeksi saluran pernafasan akut $^{6}$. Mengetahui bahwa Covid-19 adalah penyakit infeksi saluran pernafasan akut yang parah, maka sangat besar kemungkinannya bahwa kekurangan berbagai macam zat gizi mikro akan meningkatkan risiko terinfeksi virus ini?

Status gizi adalah keadaan keseimbangan antara asupan dan kebutuhan zat gizi dalam tubuh. Status gizi dapat membantu untuk mendeteksi secara dini risiko terjadinya masalah kesehatan. Banyak factor yang mempengaruhi terjadinya kekurangan status gizi, diantaranya adalah status social ekonomi, orang tua dalam hal pekerjaan orang tua, keadaan lingkungan sekitarnya, ketidaktahuan orang tua tentang pemberian gizi yang baik, persepsi orang tua melalui stimulus yang diterima ${ }^{8}$.

Dari segi gizi, dianjurkan, agar makanan sahur dipersiapkan secara lengkap empat sehat lima sempurna. Meski selera makan ketika sahur biasanya kurang baik, namun harus dipaksakan agar gizi yang dikonsumsi memenuhi syarat kuantitas dan kualitas. Agar lebih efektif, makan sahur sebaiknya dilakukan menjelang waktu imsak sehingga waktu jam puasa tidak terlalu panjang ${ }^{9}$.

This is an open-access article under the CC BY 4.0 International License

(c) Idea PengabdianMasyarakat (2021)

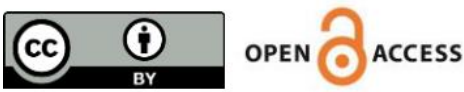


Pentingnya sikap waspada harus ditekankan kepada masyarakat untuk mencegah agar tidak terinfeksi virus ini. Kunci keberhasilan dalam mengatasi Covid-19 adalah melalui gerakan preventif untuk mempraktekkan pola hidup sehat dan membatasi kontak fisik dan menjaga jarak kontak fisik untuk memutus rantai penyebaran. Selain itu, perlu meningkatkan daya tahan tubuh terhadap infeksi dengan asupan zat gizi yang cukup dan beragam, yaitu zat gizi makro dan mikro berperan dalam meningkatkan imunitas ${ }^{10}$.

Desa Tonasa setiap bulan mengadakan pertemuan, berdasarkan kunjungan kami pada mitra dalam hal ini Sekdes Desa Tonasa menyatakan bahwa masih banyak ibu-ibu yang menyiapkan menu makanan baik sahur maupun berbuka puasa dengan cara yang tidak sehat yaitu misalnya di goreng. Ibu- ibu yang ada di Desa Tonasa berpedoman pada saat berpuasa menyiapkan menu yang praktis dan cepat.

\section{METODE}

Sasaran kegiatan ini adalah masyarakat Desa Tonasa adapun jumlah masyarakat yang ikut adalah sebanyak 15 orang hal ini disebabkan adanya pandemic dan adanya larangan berkerumun. Waktu pelaksanaan kegiatan pengabdian ini dilaksanakan pada dengan tahapan pelaksanaan sebagai berikut:

\section{Hari pertama:}

a. Koordinasi, pada tahapan ini pelaksana memperkenalkan diri dan menyampaikan teknis pelaksanaan, dengan waktu \pm 10 menit

b. Absensi, pada tahapan ini peserta diminta melakukan absensi, dengan waktu \pm 60 menit

\section{Hari kedua:}

a. Pembukaan, pada tahapan ini pelaksana menyampaikan tujuan pemberian materi, dengan waktu \pm 10 menit

b. Penyampaian materi, pada tahapan ini pelaksana penyampaian materi ( \pm 20 menit) materi yang diberikan berupa:

1. Pengertian pola makan bergizi seimbang

2. Gizi seimbang selama puasa

3. Gizi seimbang pasca puasa

4. Penutupan, pada tahapan ini disampaikan ucapan terima kasih pelaksana kepada peserta yang sudah berpartisipasi sekaligus mengakhiri kegiatan penyuluhan, dengan waktu \pm 10 menit.

Bentuk kegiatan pengabdian adalah berupa penyuluhan. Pelaksanaan kegiatan dilaksanakan selama 2 hari. Pertanyaan yang di ajukan di narasikan sebagai berikut dan menggunakan skala Guttman dengan 2 pilihan jawaban yakni "Ya" atau "Tidak".

a. Apakah anda mengetahui apa itu gizi seimbang ?

b. Apakah anda mengetahui 4 pilar gizi seimbang?

c. Apakah anda mengetahui perbedaan antara 4 sehat 5 sempurna dengan gizi seimbang?

d. Komsumsi aneka ragam makanan, perilaku hidup bersih dan sehat, aktifitas fisik dan pantau berat badan normal merupakan pilar gizi seimbang

e. Biasakan sarapan pagi sebelum beraktifitas merupakan salah satu dari pesan gizi seimbang?

f. Makanan yang mengandung sumber zat tenaga, zat pengatur dan zat pembangun adalah pengertian gizi seimbang

This is an open-access article under the CC BY 4.0 International License

(c) Idea PengabdianMasyarakat (2021)

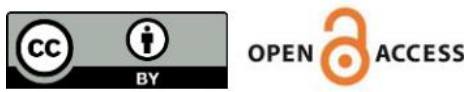


g. Makanan yang mengandung karbohidrat seperti nasi dan jagung berfungsi sebagai zat pengatur

h. Tahu, temped an telur dan ikan adalah makanan yang tidak mnegandung zat/protein

i. Hati, bayam dan telur merupakan makanan yang mengandung zat besi

j. Menjaga kesehatan janin dalam kandungan merupakan salah satu manfaat makanan bergizi untuk ibu hamil.
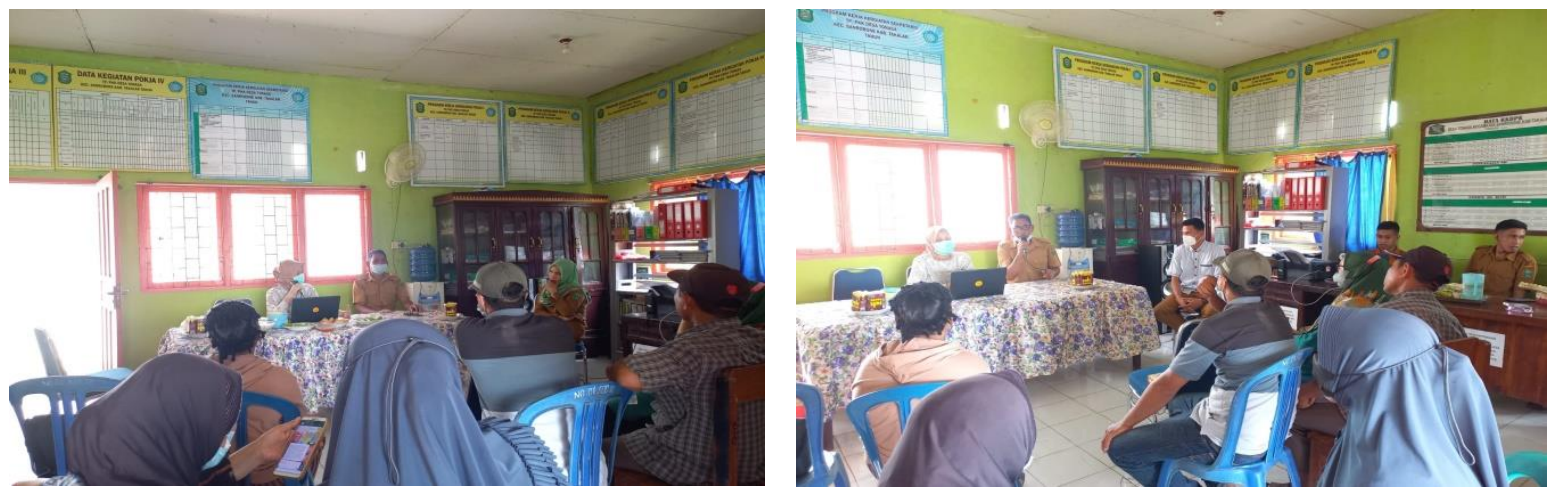

Gambar 1 dan 2. Kegaiatan Penyuluhan oleh Tim Dosen Pengabdian

\section{HASIL DAN PEMBAHASAN}

Hasil yang dicapai dari pelaksanaan kegiatan Pengabdian Masyarakat adalah peningkatan pengetahuan mengenai gizi seimbang saat puasa.berikut pre dan post test yang diberikan untuk penilaian peningkatan pengetahuan Masyarakat Desa Tonasa.

\section{Pre-Test}

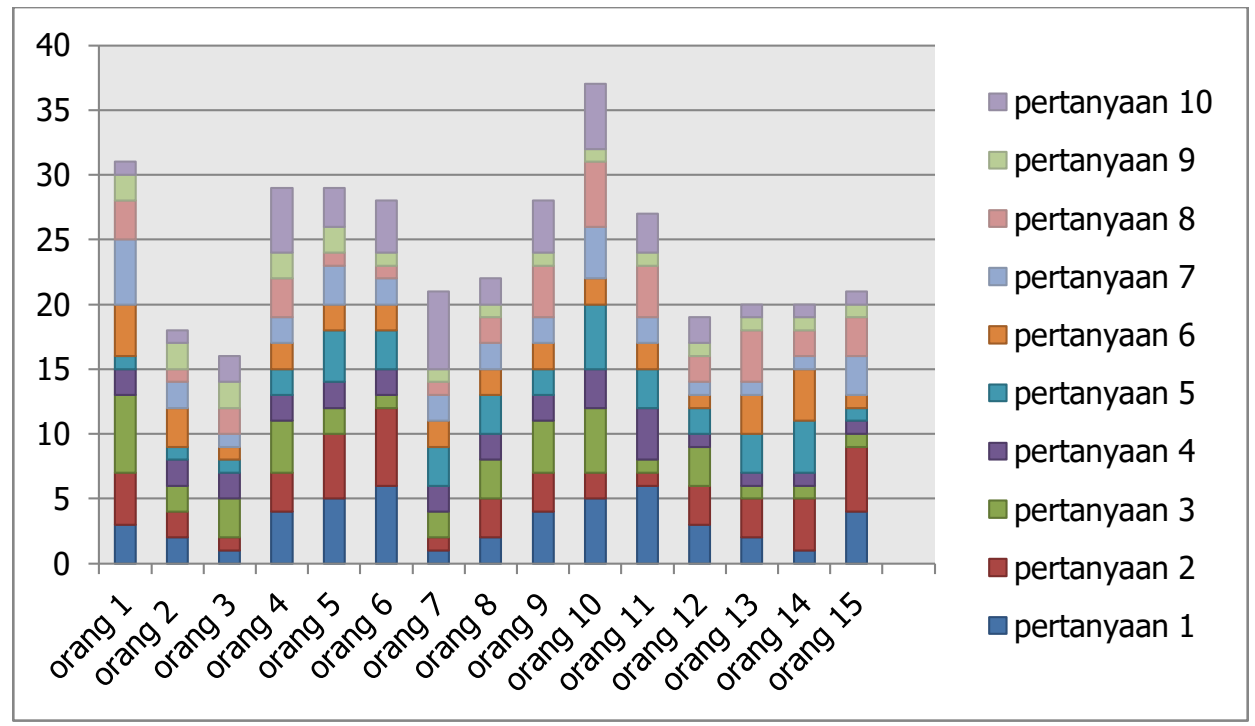

Gambar 3. Distribusi Hasil Jawaban Masyarakat di Desa Tonasa berdasarkan penilaian Pretest

This is an open-access article under the CC BY 4.0 International License

(C) Idea PengabdianMasyarakat (2021)

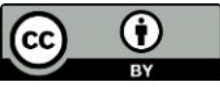


Hasil pretest menunjukkan bahwa masyarakat di Desa Tonasa mayoritas belum memahami mengenai gizi seimbang dan substitusi makanan pengganti yang memiliki takaran gizi seimbang yang sama dengan makanan sehari-hari. Pada gambar 1 menunjukkan sebagian besar masyarakat dalam menjawab pretest masih banyak yang menjawab kurang tepat terkait dengan gizi seimbang pada saat puasa. Hasil pretest secara umum mengidentifikasi bahwa pengetahuan masyarakat di Desa Tonasa mengenai Gizi seimbang selama berpuasa masih rendah, selain itu masyarakat juga belum memahami mengenai bagaimana gizi seimbang pada saat puasa.

Setelah pemberian edukasi gizi melalui penyuluhan dengan menggunakan alat Food Models dapat di identifkasi bahwa pengetahuan ibu-ibu didesa tonasa mengenai gizi seimbang pada saat puasa mengalami peningkatan yang lebih baik ini ditandai dengan adanya evaluasi dengan memberikan pertanya secara langdung kepada ibu-ibu di Desa Tonasa dan mereka dapat memahami dan bahkan menjelaskan ulang apa yang telah kami persentasikan. Sesuai dengan hasil diagram batang dibawah ini dapat dilihat adanya peningkatan pengetahuan lebih dari pre-test masyarakat di Desa Tonasa. Penyuluhan kepada Masyarakat merupakan langkah untuk mengedukasi, menambah pengetahuan dan memberikan informasi agar mereka mengerti dan mau melakukan perubahan ${ }^{11}$.

\section{Post test}

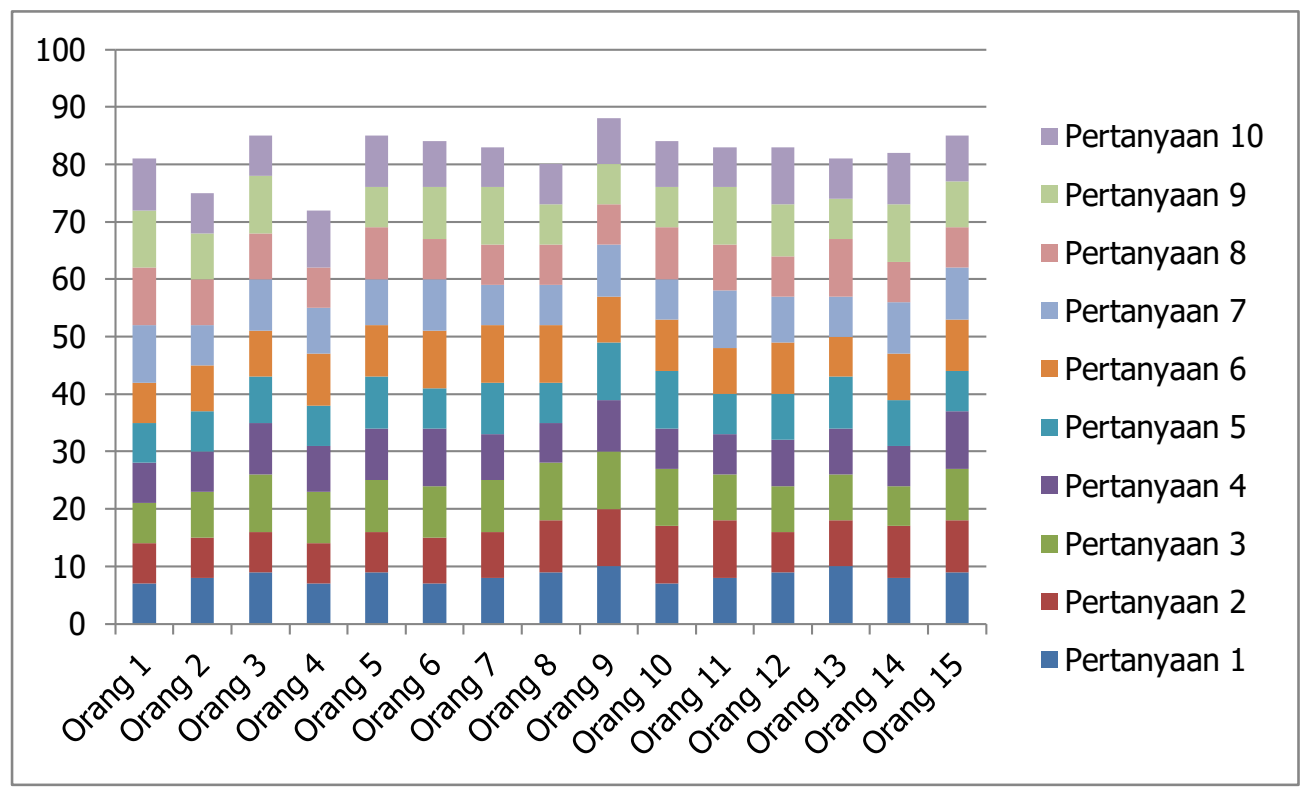

Gambar 4. Distribusi Hasil Jawaban Masyarakat di Desa Tonasa Berdasarkan Hasil Posttest

Berdasarkan hasil yang diperoleh sesuai dengan hasil post-test diatas maka dapat diketahui bahwa masyarakat di Desa Tonasa sudah memahami pola pengaturan makanan yang seimbang dan dapat mendukung aktifitas sehari-hari. 


\section{KESIMPULAN}

Kegiatan pengabdian kepada masyarakat ini dengan tema " Gizi Seimbang Pada Saat Puasa Untuk Meningkatkan Imunitas di Masa Pandemi Covid-19 Pada Ibu-Ibu di Desa Tonasa Kabupaten Gowa" hasil yang didapatkan bahwa terjadi peningkatan pengetahuan masayarakat di Desa Tonasa mengenai pentingnya pengaturan pola makanan seimbang untuk menunjang aktifitas dan pola konusmsi dimasa pandemik Covid-19. Hasil pemberian post-test secara umum mengidentifikasi bahwa terjadi peningkatan pengetahuan yang lebih baik mengenai gizi seimbang dan pola makan sehat dari pada saat evluasi pretest.

\section{UCAPAN TERIMAKASIH}

Terima kasih kepada aparat dan masyarakat Desa Tonasa, alumni mahasiswa FKM UMI.

\section{DAFTAR PUSTAKA}

1. WHO Coronavirus Disease (COVID-19). Published 2021. Accessed January 9, 2021. https://covid19.who.int/

2. Pusdatin Kementerian Kesehatan. kasus covid nasional. Published 2021. Accessed January 9, 2021. https://data.covid19.go.id/public/index.html

3. Dinas Kesehatan Provinsi Sulawesi Selatan. No Title. data pantauan covid-19 sulawesi selatan. Published 2021. Accessed January 9, 2021. https://covid19.sulselprov.go.id/

4. Septimar ZM, Rustami M, Wibisono AY. Jurnal Menara Medika https://jurnal.umsb.ac.id/index.php/menaramedika/index JMM 2020 p-ISSN 2622-657X, e-ISSN 2723-6862. J Menara Med. 2020; 3 (1) : 66 - 73.

5. Weylandt, K.H. ., Serini S., CHen, Y.Q., Su, H.M., Lim. K., Cittadini A, \& Calviello G. Omega-3 polyunsaturated fatty acids. W times Mix Evid BioMed Res Imternational, 2015. Published online 2015. https://doi.org/10.1155/2015/143109.

6. Gombart, A. F., Pierre, A.,\& Maggini S (2020). A Review of Micronutrients and the immune system-working in harmony to reduce the risk of infection. Nutrients. 2020;12(1). https://doi.org/10.3390/nu12010236

7. Sri Sumarni. Kerja Harmoni Zat Gizi dalam Meningkatkan Imunitas Tubuh Terhadap Covid-19. $\boldsymbol{A}$ Mini Rev Publ by IAGIKMI Univ Airlangga. Published online 2020:250-256. 10.20473/amnt. v4i3

8. Khomsan A. Dampak Kesehatan Puasa dalam Pangan dan Gizi untuk Kesehatan. Dep Gizi Masy Fak Ekol Mns, IPB, Bogor. Published online 2005.

9. Khomsan A. Puasa, Gizi dan Kesehatan dalam Pangan dan Gizi Kesehatan. RAja Graf Press Jakarta. Published online 2002.

10. Salman Y, Baru B. Edukasi gizi untuk meningkatkan imunitas tubuh ( Asupan tepat di masa pandemi Covid-19 ). Edukasi gizi untuk Meningkat imunitas tubuh ( Asupan tepat di masa pandemi Covid-19). 2021;3(1):20-29.

11. Amir H, Agus AI, Bima MIM, As'ad I, Hafid MF, Ashar JR, Zainal AQ, Jihad A, Musda GH. Penerapan 3M dalam Mencegah Penularan Covid-19 di Desa Lonjoboko Kabupaten Gowa. Idea Pengabdi Masy. 2021;1(1):1-4. 